\title{
CORNELIS P. WELTEN
}

\section{I929-I970}

On i7th February 1970 ASTIN lost one of its most prominent members, C. P. (Kees) Welten, after a long exhausting illness, which had already taken a grip on him in $\mathbf{I} 969$.

At the young age of 40 , while he was making plans for the near and more distant future, the inevitable happened - at a time when the expectation of his future activities was still so great.

For the many colleagues, at home and abroad, the death of Welten means a great loss, not only in the academic field, but also in the social sphere, since Welten, like no one else, continued to make friends by his open and honest nature.

Welten entered the actuarial profession early and had already obtained his qualifications at the age of 23. During his years of study he worked for the most part at the Rijksverzekeringsbank (Bank of State Insurance), which carried out a few insurance laws. Soon after obtaining his final actuarial diploma, he turned to the field of consulting practice, where at the youthful age of 28 he became a partner of the firm Brans \& Co.

Welten's academic interests went beyond the normal actuarial routine. He therefore soon became an enthusiastic member of ASTIN. Like few others, he could evaluate the new studies in the field of non-life business and develop them further. His capacities were recognised by his election to the ASTIN Committee, by his work as co-editor and later as editor of the ASTIN Bulletin, in which he also wrote a few articles himself. He was also elected as committee-member of the ASTIN section of the Dutch Institute of Actuaries. The ASTIN Colloquia always held his special interest, and he carried out an important part of the work, for example, in the organization of the Arnhem Colloquium. How very sorry he was that his illness already prevented him from going to Sopot, although he had made all the necessary arrangements.

On the international scene Welten was also asked to become a committee-member of the I.A.A., to act as National Correspondent 
for the Netherlands. Unfortunately however, he was no longer entirely able to accept this position.

In the Netherlands as well, Welten was frequently willing to give lectures or lead discussion groups, and this alongside his exacting consulting practice. From his pen flowed numerous articles in Dutch periodicals, whilst an important contribution of his was also taken up in the Jubilee Number of A.R.C. In short, he was one of the promising young actuaries.

His passing away at such an early age makes us realise what a vacuum is left behind with all of us who had any connection with him.

May his wife especially - also for the sake of their three children find the strength to accept this loss.

H. LANGHORST 